\title{
ІНФОРМАЦІЙНА ТЕХНОЛОГІЯ ОЦІНКИ СТАНУ СЕРЦЕВО-СУДИННОЇ СИСТЕМИ З ВИКОРИСТАННЯМ МЕТОДІВ МОРФОЛОГІЧНОГО АНАЛІЗУ ОСЦИЛОГРАМИ
}

\author{
Д. В. Вакуленко, Л. О. Вакуленко, Д. В. Козак \\ ДВНЗ «Тернопільський державний медичний університет \\ імені І. Я. Горбачевського МОЗ України»
}

\begin{abstract}
Інформаційні технології морфологічного аналізу осцилограм: ритмічність, частота, форма, амплітуда осциляцій та тривалість їх фраз, а також наявність, розміри, локалізація дикротичного зубця і додаткових хвиль на низхідній частині осциляцій та їх динамка в процесі зростання компресії дають можливість оцінити не лише рівень артеріального тиску, але і стан периферійних судин, функціональну спроможність серцево-судинної системи та механізми її адаптації до компресії судин передпліччя манжетою.
\end{abstract}

Ключові слова: інформаційні технології, морфологічний аналіз осцилограм

\section{ИНФОРМАЦИОННАЯ ТЕХНОЛОГИЯ ОЦЕНКИ СОСТОЯНИЯ СЕРДЕЧНО- СОСУДИСТОЙ СИСТЕМЫ С ИСПОЛЬЗОВАНИЕМ МЕТОДОВ МОРФОЛОГИЧЕСКОГО АНАЛИЗА ОСЦИЛЛОГРАММ}

\author{
Д. В. Вакуленко, Л. А. Вакуленко, Д. В. Козак \\ ГВУЗ «Тернопольский государственный медицинский университет \\ имени И. Я. Горбачевского МЗ Украины»

\begin{abstract}
Информационные технологии морфологического анализа осцилограмм: ритмичность, частота, форма, амплитуда осцилляций, длительность их фаз, а также наличие, размеры, локализация дикротического зубца и дополнительных волн на нисходящей части осцилляций, их динамика в процессе увеличения компрессии дают возможность оценить не только уровень артериального давления, но и состояние периферических сосудов, функциональную способность сердечно-сосудистой системы и механизмы её адаптации к компрессии сосудов плеча манжетой.
\end{abstract}

Ключевые слова: информационные технологии, морфологический анализ осциллограмм

\section{INFORMATION TECHNOLOGY MORPHOLOGICAL ANALYSIS OF ARTERIAL WAVEFORMS}

\author{
D. V. Vakulenko, L. O. Vakulenko, D. V. Kozak \\ SHEI «Ternopil State Medical University by I. Ya. Horbachevsky of MPH of Ukraine»
}

\begin{abstract}
Information technology of morphological analysis of waveforms: rhythm, frequency, shape, oscillation amplitude, the duration of their phases, and the presence, size, localization of the dicrotic notch and additional waves in the descending part of oscillations, their dynamics in the process of increasing the compression enable us to estimate not only the level of blood pressure but the state of the peripheral vessels, the functional capacity of the cardiovascular system and the mechanisms of its adaptation to receptacles compression arm cuff.
\end{abstract}

Key words: information technology, morphological analysis of arterial oscilogram.

Вступ. Інноваційні процеси, що відбуваються в сучасному суспільстві, безсумнівно, торкнулися і медичної галузі. Обумовлені ними структурні та організаційні перетворення в сфері охорони здоров'я потребують переосмислення багатьох по- стулатів, активізації резервів, і головне - залучення найсучасніших технологій [1].

В першу чергу це відноситься до найпоширеніших захворювань людства - захворювань серцевосудинної системи. Значною мірою благополуччя 
кровообігу залежить від стану судин - «периферійного серця» (за М. В. Яновським) [2]. Одним із методів його оцінки є осцилографія, діагностичні можливості якої потребують подальшого удосконалення. Застосування сучасного електронного обладнання може сприяти підвищенню інформативності указаного методу дослідження.

Мета досліджень - розробити критерії для проведення морфологічного аналізу осцилограм артеріальних судин. Вивчити динаміку морфологічної картини осцилограм в процесі зростання компресії судин передпліччя манжетою. Розробити рекомендації щодо вивчення та оцінки стану серцевосудинної системи шляхом аналізу осцилограм за їх морфологічними характеристиками.

Матеріал та методи дослідження. Для вирішення поставленої мети нами в пакеті MatlabR2010 у 400 практично здорових осіб з кривої артеріального тиску, отриманої за допомогою електронного вимірювача тиску ВАТ41-2, виділено артеріальні осцилограми та проведено їх морфологічний аналіз. Формування та запис кривої відбувався в автоматичному режимі, синхронно 3 нагнітанням манжети і реєстрацією відповіді артерії на компресію шляхом зміни об'єму манжети протягом усього періоду компресії.

Для морфологічного аналізу осцилограм використано наступні критерії: а) форма осцилограми (характеристика огинаючих, ритмічність пульсацій, рівномірність зростання та зниження амплітуди осциляцій в процесі збільшення компресії); б) наявність та кількість максимальних осциляцій $з$ однаковою амплітудою; в) характер окремих осциляцій в різних фазах компресії (їх амплітуда, кути екстремумів, висхідна та низхідна частини); г) наявність, локалізація, величина дикротичної та додаткових хвиль на окремих осциляціях.

Для зручності візуального аналізу осцилограми, залежно від стадії зростання компресії, нами виділено три їі частини (рис. 1).

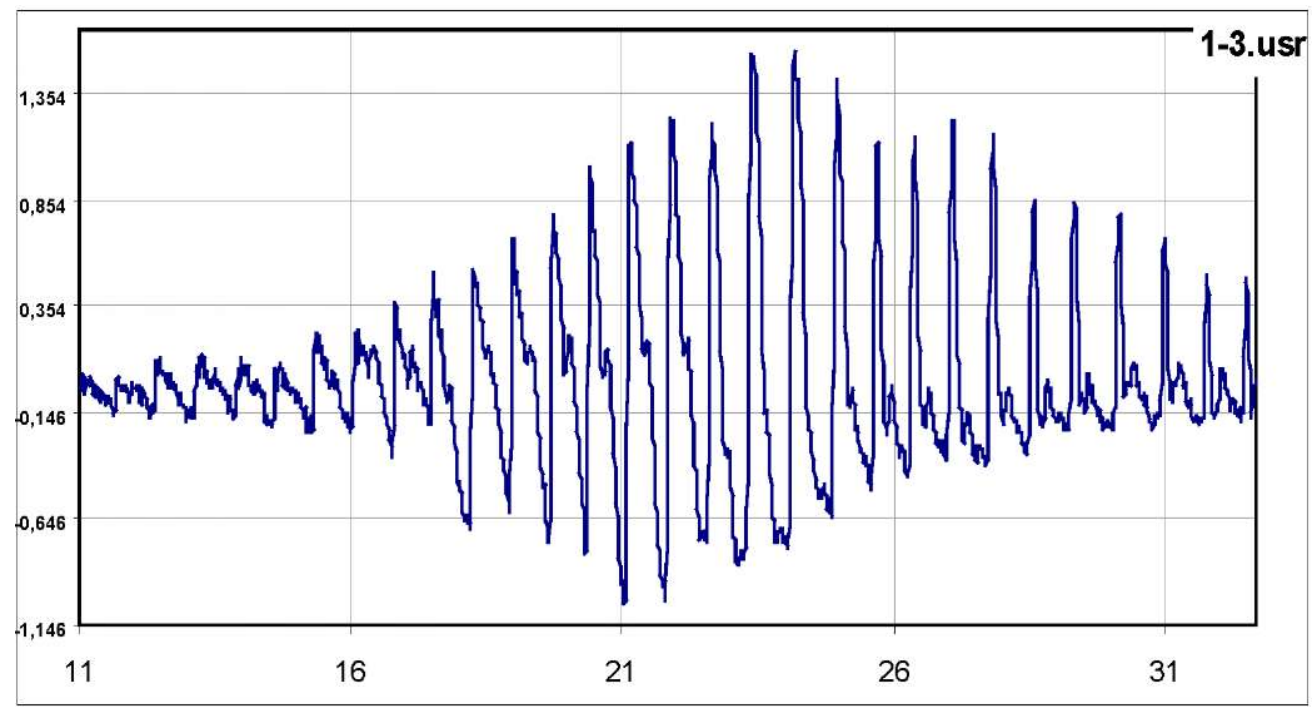

Puc. 1. Осцилограма судин плеча обстеженого М, 20 років.

Примітка. По осі X - час реєстрації осцилограми (с), по осі Y- значення коливань тиску в манжеті під впливам судинної стінки артерії (мм рт. ст.).

Перша - початок компресії (від початку компресії до моменту стрімкого зростання амплітуди осциляцій, значення діастолічного тиску, у нашому прикладі - до 18 с, друга - наростання компресії (від моменту стрімкого зростання амплітуди осциляцій до їі стрімкого зниження, значення систолічного тиску - 18-31 с), третя - максимальної компресії (тиск у манжеті більший від рівня систолічного тиску - 32-33 c) [6]. У свою чергу, друга частина включала період 2-а - iї висхідна частина (період нарос- тання компресії до досягнення повного стиснення судин у фазі діастоли, 18-23 с) і 2-б - ï максимальні осциляції та низхідна частина (до досягнення повного стиснення судин у фазі систоли, 23-31 с) [3].

Результати досліджень та їх аналіз. Зіставлення аналізу літературних джерел 3 отриманими нами результатами досліджень, дало можливість дати характеристику обраних для морфологічного аналізу критеріїв. Для прикладу обрано осцилограми двох практично здорових осіб. 


\section{Приклад 1}

Використано одну з типових із зареєстрованих нами осцилограм (рис. 1) пацієнта М., 20 років, практично здорового, артеріальний тиск 109 і 63 мм рт. ст.):
Огинаючі. Для візуального аналізу форми осцилограми за показниками максимальних та мінімальних екстремумів осциляцій, розміщених по обидва боки відносно осі X, побудовано огинаючі (рис. 2) [3].

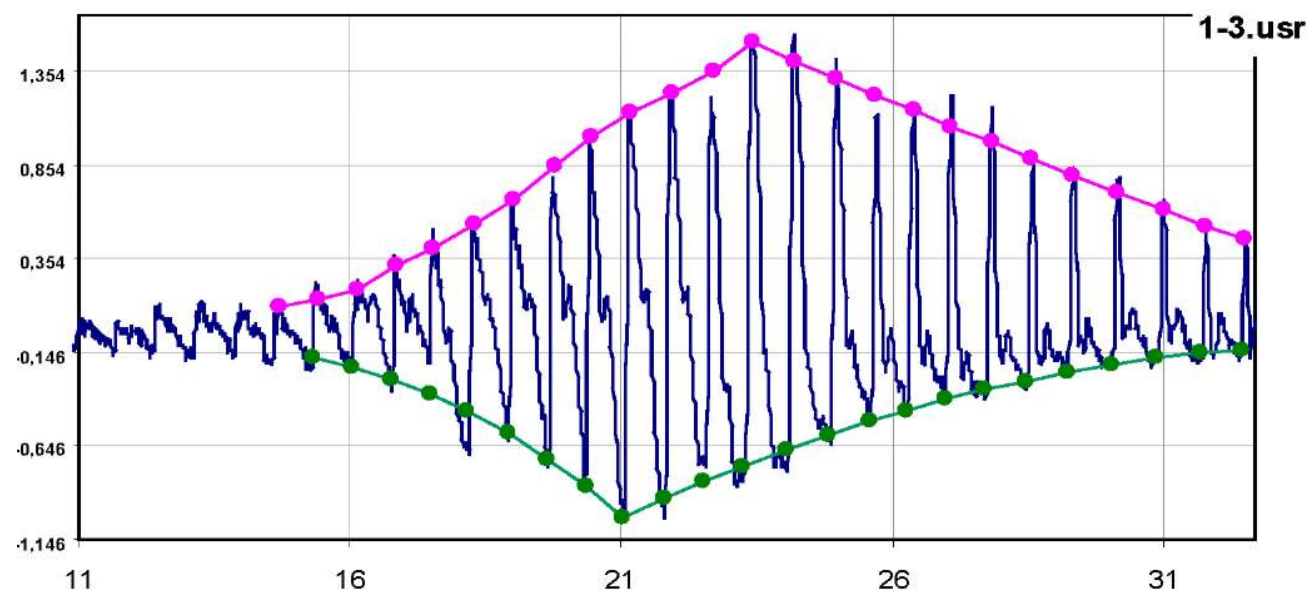

Puc. 2. Огинаючі за максимальними та мінімальними екстремумами осцилограми судин плеча обстеженого М, 20 років.

Примітка. По осі $X$ - час реєстрації осцилограми (c), по осі $Y$ - значення коливань тиску в манжеті під впливам судинної стінки артерії (мм рт. ст.).

При аналізі огинаючої за максимальними екстремумами відмічено тї куполоподібну форму: поступове рівномірне зростання до 24 секунди вимірювання (до повного перетискання судини у фазі діастоли), наявність вершини, зумовленої двома максимальними екстремумами (23,5-24 с) та поступове зниження іiї до припинення компресії (до 33 c). При цьому окремі вершини осциляцій дещо відхиляються від огинаючої в бік їх зниження чи підвищення. Огинаюча, побудована за нижніми екстремумами, має практично аналогічну форму, лише в протилежних значеннях. Пік вершини огинаючої за мінімумами (21-22 с) дещо випереджає пік максимумів (23,5-24 с).

Таким чином, симетричне розміщення огинаючих, створених за максимальними та мінімальними екстремумами, їх куполоподібна форма 3 рівномірним зростанням та зниженням, поява піків за максимумами слідом за мінімальними свідчить про адекватну реакцію судин передпліччя на поступово зростаючу компресію.

загальний візуальний аналіз осцилограми. При загальному візуальному аналізі осцилограми (рис. 1) привертає увагу іï певна гармонійна форма: поступове зростання амплітуди осциляцій, досягнення максимуму на 23-24 с та зниження до кінця реєстрації. Це свідчить про те, що амплітуда кожної пульсової хвилі пропорційна змінюваному під впливом тиску в манжеті просвіту магістральної артеріальної судини [4] і вказує на адекватну рефлекторну реакцію серцево-судинної системи обстежуваного на різні рівні поступово зростаючої компресії судин плеча. За висотою осциляцій можна судити про тонус та прохідність судин, серцеву діяльність, стан вегетативної нервової системи, артеріальний тиск та нервово-рефлекторні впливи на їх стан [5].

Привертає увагу виражене зростання амплітуди осциляцій на 18 с та зниження їх на 32 с. Перше показник діастолічного тиску (початок компресії судин у фазі діастоли) і є результатом початку стрибкоподібного зростання різниці між площею просвіту судини в діастолі і систолі. Другий - показник систолічного тиску, коли указана різниця дорівнює нулю [4].

Тривалість висхідної частини осциляцій відображає потужність пульсової хвилі, створеної систолічним викидом. Прискорення крові на початку фази вигнання виникає дуже швидко, але дуже короткочасно [6]. Тривалість низхідної частини осциляцій (фази повільного вигнання крові та діастоли) більша. Це зумовлено тим, що великі судини, у тому числі аорта - судини еластичного типу, тому протягом систоли вони діють як ємність, яка нако- 
пичує частину вигнаного об'єму крові, який потім, під час діастоли, проштовхується в периферійні судини [6]. Ступінь розтягнення судин залежить від пружноеластичних властивостей судинної стінки, які зумовлені особливостями їх структури (індивідуальними, віковими, патологічними), тонічним напруженням м'язового шару судинної стінки, ступенем пасивного напруження судинної стінки і підлягають нервово-рефлекторним впливам [4].

Динаміка площ висхідної та низхідної частин осциляцій в процесі збільшення компресії, отриманих за допомогою математичного аналізу осцилограм, зображені на рисунку 3.

\section{Площа фаз осциляцій}

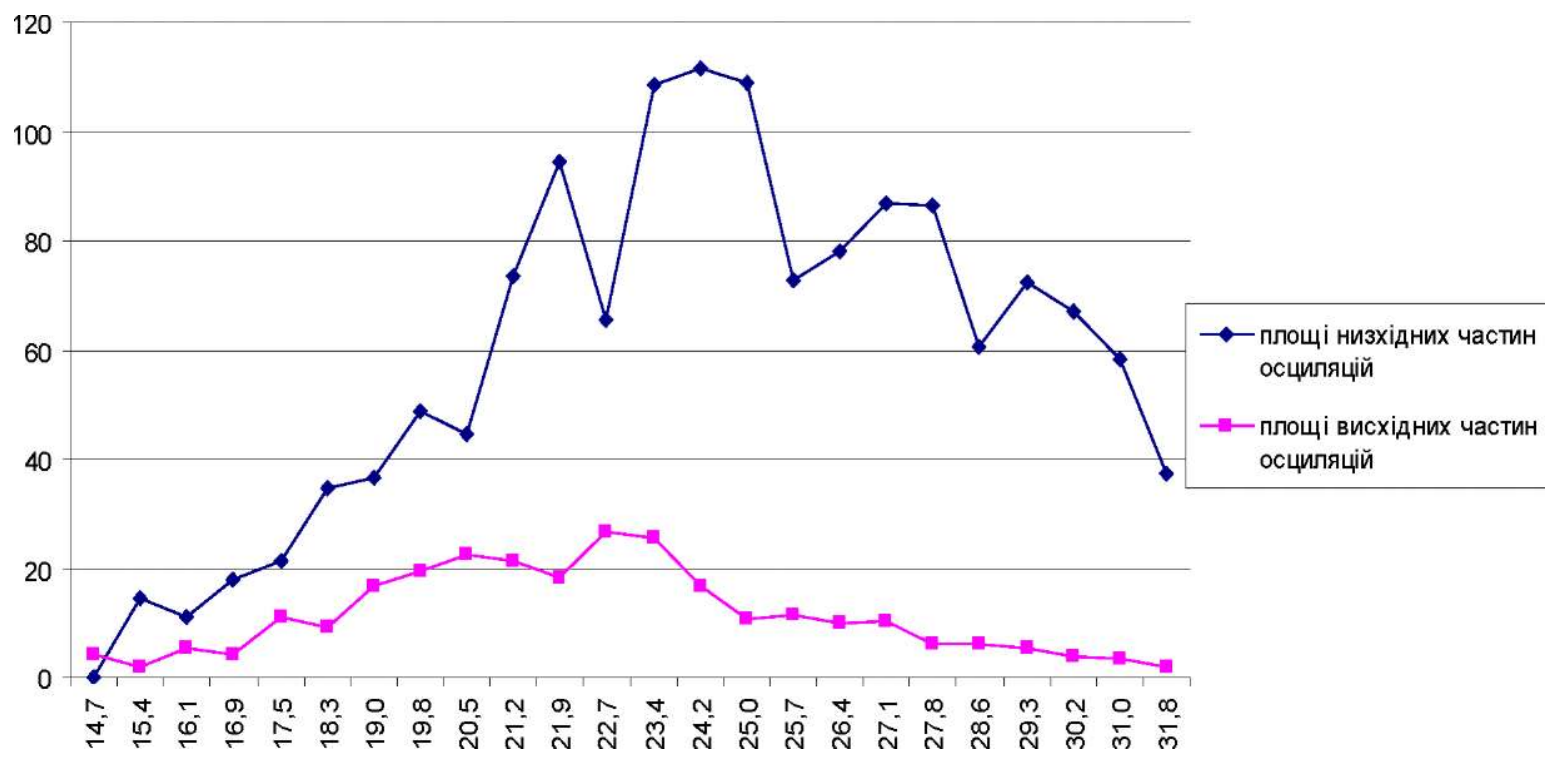

Puc. 3. Площі висхідної та низхідної частин окремих осциляцій в процесі наростання компресії судин плеча обстеженого М, 20 років.

Примітка. По осі X - час реєстрації окремих осциляцій (c), по осі $Y$ - площча фаз осциляцій.

Як видно з рисунка, в процесі зростання компресії площа висхідної частини осциляцій змінюється незначно, тоді як низхідної частини - зростає більшою мірою. Пік зростання площ відповідає початку повного стискання судин плеча під час діастоли, в процесі наростання компресії вони зменшуються. На максимальних осциляціях висхідна частина займає 14,5 \% площі усієї осциляції, низхідна - 85,5 \%. Вони співвідносяться між собою як 1:5,9.

Привертає увагу наявність на низхідній частині осциляцій, в кінці систоли, дикротичної хвилі, яка $€$ початком діастоли. Вона зумовлена приходом відбитої хвилі, що виникає внаслідок короткого періоду зворотного руху крові при відбитті гідравлічної хвилі від замкнутого аортального клапана та поширенням її на периферію [4, 6, 7].

На початку компресії (частина 1 та 2-а) дикротична хвиля розміщена на середній частині катакроти, зникає при максимальній амплітуді осциляцій, в процесі наростання компресії (період 2-б та 3) з'являється знову, але вже на нижній пї частині. Останнє свідчить про збільшення тривалості фази повільного вигнання крові в процесі зростання компресії [4]. Воно зумовлене утрудненням току крові на рівні судин передпліччя, що створює в розташованих проксимально від них артеріях гальмування потоку і умови для стиснення крові в період вигнання ii систолічного об'єму 3 шлуночків. При цьому лівому шлуночку необхідно докласти більше зусиль, щоб подолати підвищений тиск в аорті [6].

Вершини верхніх екстремумів загострені. На початку компресії вони наближаються до $45^{\circ}$, що указує на наявність короткого періоду рівноваги між притоком крові в магістральні артерії і їі відтоком в периферійні судини [4]. В процесі зростання компресії ця фаза зникає. Кути вершин максимумів 
зменшуються, а у період 2-б та 3 - наближаються до нуля: верхня частина катакроти значно наближається до анакроти або збігається з нею. При цьому відстань між максимумами пульсацій (зумовлених поширенням пульсової хвилі) залишається незмінною за рахунок низького розміщення дикротичного зубця, появи дрібних осциляцій в кінці діастоли, які утримуються до появи наступного гідравлічного удару пульсової хвилі. Їх кількість та форма зумовлені пружноеластичною здатністю стінки судин передпліччя та нервово-рефлекторними механізмами регуляції артеріального тиску у відповідь на зростання компресії [6].

На нижніх екстремумах - у частині 1 та 2-а реєструються переважно гострі кути. При досягненні максимальної амплітуди на їх вершинах виникають дрібні осциляції, які зникають в процесі зростання компресії та появи на катакротичній частині осциляцій дикротичного зубця. Впродовж подальшого зростання компресії загострені вершини реєструються знову, а потім сплощуються за рахунок накладання на них дрібних хвиль.

Аналіз першої частини осцилограми (рис. 1). В початковий період обтискання плеча, коли компресія лише наростає і не має суттєвого впливу на його кровообіг, виникає можливість оцінити стан серцево-судинної системи в спокої [4]. В міру наростання компресії амплітуда пульсацій рівномірно збільшується за рахунок підвищення тиску в манжеті. На низхідній частині осциляцій, окрім дикротичної хвилі, реєструються дрібні додаткові хвилі різної кількості, розмірів та локалізації [6, 7]. Флуктуації на записах тиску різноманітні і чисельні, тому розцінити яку-небудь 3 них як наслідок відбиття хвиль від аортальних клапанів не завжди вдається [7,8].

Указані реакції зумовлені (в першу чергу) механізмами термінової реакції на компресію. До них відносять циркулярні реакції нервового походження - барорецепторні, хеморецепторні, рефлекс на ішемію центральної нервової системи та ін., які контролюють різні параметри кровообігу і постійно інформують центральну нервову систему про зміни, що виникають [9]. Неоднорідність реакції судинної стінки на наростання компресії зумовлена станом нервово-рефлекторних механізмів регуляції артеріального тиску та в'язко-пружними властивостями судинної стінки [6].

Однорідність реакції судинної стінки на наростання компресії на осцилограмі обстеженого М свідчить про задовільний стан нервово-рефлекторних механізмів регуляції артеріального тиску та в'язкопружних властивостей судинної стінки.

Аналіз другої частини осцилограми (рис. 1). На початку другої (2-а) частини (починаючи 318 c), коли просвіт судин починає зменшуватися (тиск в манжеті протидіє повному розкриттю судин плеча до попередніх розмірів у фазі діастоли), амплітуда осциляцій різко зростає і продовжує збільшуватись в міру зростання компресії та різниці між площею просвіту судин під час діастоли і систоли [4].

На низхідних частинах осциляцій реєструються чітко виражені дикротичні зубці, які з кожною наступною осциляцією наближаються до середньої частини катакроти і поступово зникають в процесі зростання компресії.

На 23,5 та 24 секундах зареєстровано два екстремуми 3 найбільшими значеннями амплітуд. Перша 3 максимальних амплітуд свідчить про показник середнього гемодинамічного артеріального тиску, зумовленого найбільшою різницею просвіту досліджуваних судин (під час діастоли судини повністю перетискаються, під час систоли їх просвіт відновлюється) [4].

Друга, подібна за амплітудою максимальна осциляція, не зважаючи на зростання компресії залишається без змін, що вказує на те, що різниця між площею просвіту судин в діастолі і систолі не змінюється. Це свідчить про бічний артеріальний тиск - тиск крові на артеріальну стінку в період систоли шлуночків $[4,6]$. В даний період поступлення максимально можливого об'єму крові в судину зумовлене радіальним розширенням стінок судин під час систоли (завдяки їх пружності) та поверненням у вихідне положення під час діастоли, коли тиск падає [7]. Пружні властивості стінки судин забезпечуються волокнами трьох типів: еластичними, колагеновими, гладком'язовими [7]. Тонічне напруження судинної стінки і ступінь iii пасивного розтягнення зумовлені нервоворефлекторним впливам [10]. Клінічне значення бічного систолічного тиску полягає в тому, що виникає можливість за його рівнем визначити істинний тиск під час систоли, істинну пульсову амплітуду [4] та пружноеластичні властивості стінки судин [11].

За даними осцилограми, зображеної на рисунку 1 , максимальний тиск, з яким в період максимальних осциляцій судини плеча здійснюють свій вплив на манжету під час систоли - +1,4 мм рт. ст., а стискання судини манжетою під час діастоли $-1,1$ мм рт. ст. 
На осциляціях 3 максимальними амплітудами дикротичний зубець відсутній. В цей час на мінімальних екстремумах з'являються різнохарактерні дрібні осциляції, що зумовлені індивідуальною реакцією судинної стінки на початок повного закриття судин у фазу діастоли.

В міру зростання компресії, після досягнення повного перетискання судин у фазі діастоли, амплітуда хвиль знижується внаслідок неповного розкриття магістральної артеріальної судини під час систоли (зменшення різниці між площею просвіту судин в діастолі і систолі) [4]. У нашому прикладі за максимальними слідує дві осциляції 3 меншою амплітудою, ніж наступні (25-26 с), що $\epsilon$ результатом утруднення проштовхування крові в периферійні судини [11] і свідчить про стан координації місцевих саморегуляторних механізмів та центральної нейрогуморальної регуляції діяльністю серцево-судинної системи [9]. У обстежуваного діяльність останніх на достатньому рівні: цей період був короткотривалий, усього дві пульсові хвилі. За ними реєструвалось рівномірне зниження амплітуди осциляцій.

Дикротична хвиля в процесі зростання компресії зміщується до нижньої частини катакрти. Ï̈̈̈ амплітуда поступово збільшується. Це можна пов'язати зі зростанням величини зворотного потоку крові за рахунок розтягнення судин, розміщених між місцем вимірювання і серцем [6], i $є$ свідченням продовження зв'язку рецепторного апарату i нейром'язових елементів судин 3 центральною нервовою системою, що зберігає дію фізіологічних механізмів регуляції артеріального тиску і стану кровоносних судин [10].

За дикротичною хвилею реєструється плавний спуск кривої, який відповідає рівномірному відтоку крові під час діастоли. Ї̈̈ розміри зменшуються в процесі зниження рівня локалізації дикротичної хвилі, що свідчить про утруднення для відтоку крові, зумовлене наростаючою компресією [6].

При досягненні в манжеті тиску рівного систолічному артеріальному тиску, судини закриваються, кровотік у них припиняється. На це указує остання 3 найвираженіших осциляцій (перед їх різким зниженням) у кінці осцилограми (на 31 с) [5].

Аналіз третьої частини осцилограми. У третій частині осцилограми (рис. 1), (після 32 секунди) амплітуда осциляцій різко зменшується, що зумовлено повним стисненням артерії у фазі систоли. На цьому етапі пульсації зумовлені поширенням гідравлічної хвилі по стиснутих судинах $[5,6]$. Хвиля, що реєструється при цьому, уже не на низхідній частині осциляції, а після неї $(32,5$ c), свідчить про повне стиснення судин під час систоли. Вона зумовлена гідравлічним ударом, «перекиданням» пульсової хвилі та утворенням ударної хвилі, яка виникає при несподіваній появі перешкоди перед потоком крові [6]. Однотипні дрібні осциляції є результатом дії інерційних сил в період, коли судина повністю стиснута. Вони утримуються до появи наступного гідравлічного удару $[6,7]$.

Таким чином, аналіз досліджень показав, що для осцилограми практично здорової особи (рис. 1) [12] притаманне наступне:

I. Форма осиилограми

1. Ритмічність осциляцій, поступове рівномірне зростання їх амплітуд, досягнення максимуму та зниження до кінця реєстрації.

2. Збереження в процесі зростання компресії декількох однакових за амплітудою максимальних осциляцій (в період початку повного перетискання судин під час діастоли).

3. Симетричне розміщення огинаючих, створених за максимальними та мінімальними екстремумами, їх куполоподібна форма $з$ рівномірним зростанням та зниженням, поява піків за максимумами слідом за мінімальними екстремумами.

4. Більш виражене зростання амплітуди осциляцій на висхідній частині осцилограми - показник діастолічного, зниження на низхідній - систолічного тиску.

II. Характер окремих осииляцій в різних фазах компресіі

1. Амплітуда кожної пульсової хвилі пропорційна змінюваному під впливом тиску в манжеті просвіту магістральної артеріальної судини: поступово зростає, досягає максимуму і поступово знижується.

2. Вершини верхніх екстремумів загострені. На початку компресії їх кут більший, в процесі зростання компресії - спочатку зменшується, а потім наближається до нуля: верхня частина катакроти значно наближається до анакроти або збігається 3 нею.

3. Площа висхідної частини менша, низхідної - більша. Вони співвідносяться між собою як 1 до 6.

4. Тривалість фази повільного вигнання крові в процесі збільшення компресії поступово зростає, фаза діастоли - скорочується. 
III. Наявність, локалізачія, величина дикротичної та додаткових хвиль на окремих осииляціях

1. На висхідній частині осциляції додаткові хвилі відсутні.

2. На низхідній частині осциляцій, в кінці систоли, реєструється дикротична хвиля. На початку компресії вона розміщена на середній частині катакроти, зникає при максимальній амплітуді осциляцій. В процесі наростання компресії з'являється знову, але вже на нижній частині катакроти, і в кожній наступній пульсації поступово наближається до їі нижнього краю. Амплітуда дикротичної хвилі при цьому зростає.

3. В процесі зростання компресії на низхідній частині осциляцій слідом за дикротичною хвилею, реєструються дрібні однотипні додаткові хвилі.
4. Повну компресію судин (або систолічний тиск) можна визначити не лише за стрімким зменшенням амплітуди осциляцій, але і за зникненням дикротичної хвилі на низхідній частині. Поява хвилі слідом за закінченням катакротичної фази - ознака повного стиснення судин як у фазі діастоли, так і систоли.

5. Однотипні дрібні осциляції в період, коли судина повністю стиснута, є результатом дії інерційних сил. Вони утримуються до появи наступного гідравлічного удару.

\section{Приклад 2.}

Для порівняння використана осцилограма практично здорової особи, юнака С, 20 років, який займається вільною боротьбою, має 1-й спортивний розряд. АТ - 129 і 70 мм рт. ст. (рис. 4).

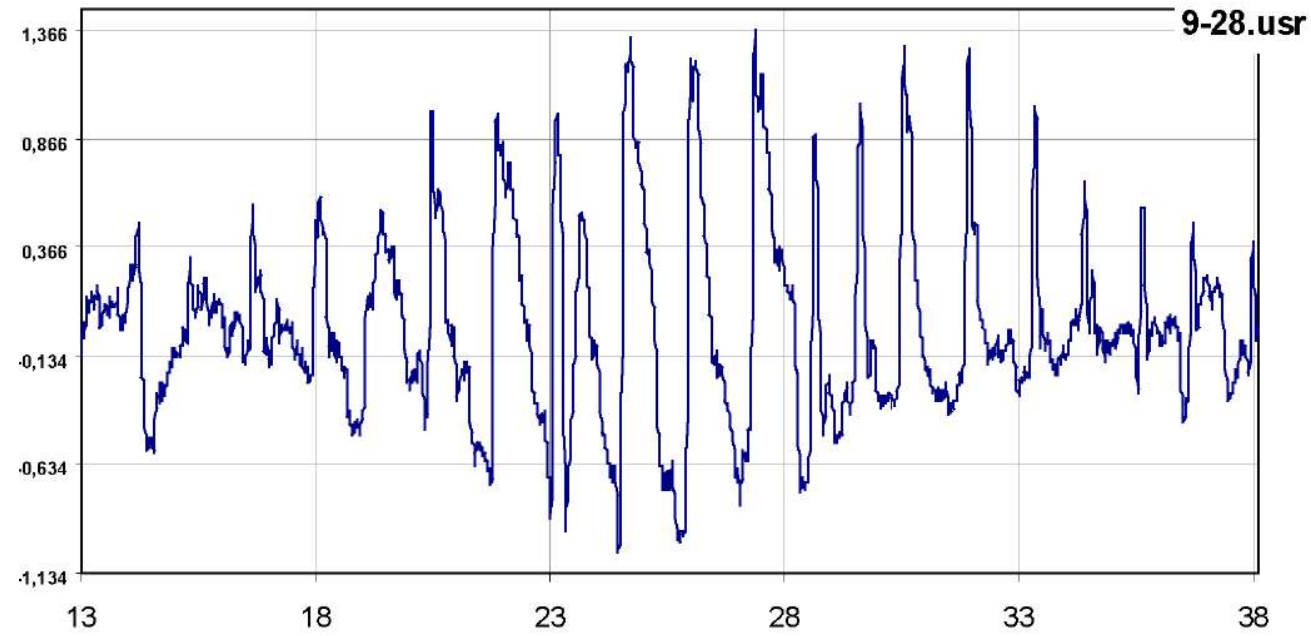

Puc. 4. Осцилограма судин плеча обстеженого С, 20 років.

Примітка. по осі X- час реєстрації осцилограми (c), по осі Y-значення коливань тиску в манжеті під впливом судинної стінки артерії (мм рт. ст.).

При аналізі даної осцилограми привертає увагу відсутність гармонійного зростання та зменшення амплітуди осциляцій, кутів максимумів, закономірностей в наявності та розміщенні дикротичної хвилі (для прикладу - 21, 22, 23, 24 с). За дикротичною хвилею реєструються різнохарактерні за розмірами та локалізацією додаткові хвилі (1 та 3 частини осцилограми), спуск кривої до меж нижчих, ніж при попередній осциляції (19, 22 с), пресистолічні хвилі $(29,32,34,35$ с). На 19 с на висхідній частині зареєстровано додатковий зубець. На 14 секунді наростання компресії пульсова хвиля виявилась більшою, ніж попередня і наступна. Після 23 с з'являється позачергова пульсова хвиля, що свідчить про порушення ритму серцевої діяльності [9]. Указані дані свідчать про порушення функціонального стану судин плеча, неадекватну реакцію судинної стінки на наростання компресії у спортсмена С.

Висновки. Застосування інформаційних технологій дало можливість на основі аналізу осцилограм розробити морфологічні критерії оцінки стану судин плеча.

Критеріями морфологічного аналізу осцилограм $€$ : ритмічність, частота, форма, амплітуда осциляцій та тривалість їх фаз, а також наявність, розміри, локалізація дикротичного зубця і додаткових хвиль на низхідній частині осциляцій та їх динамка в процесі зростання компресії.

Морфологічний аналіз характеру осцилограми, отриманої в процесі поступової компресії судин, $\epsilon$ достатньо інформативним для оцінки стану 
периферійних судин та функціональної спроможності серцево-судинної системи адаптуватися до компресії судин плеча. Результати досліджень можуть бути використані як в клінічній, так і в

\section{Література}

1. Панченко О. А. Применение информационных технологий в современной реабилитологии / О. А. Панченко, О. П. Минцер. - К. : КВИЦ, 2013. - 136 с.: ил

2. Аринчин Н. И. Периферические «сердца» человека. Н. И. Аринчин. - Мн. : Наука и техника, 1980. - 236 с. 3. Вакуленко Д. В. Інформативне значення окремих показників осцилограм судин верхньої кінцівки, зареєстрованих в процесі вимірювання артеріального тиску. / Д. В. Вакуленко // Медична інформатика та інженерія. - 2013. - № 4. - С. 67-80.

4. Комплекс аппаратно-программный неинвазивного исследования центральной гемодинамики методом объемной компрессионной осциллометрии «КАП ЦГ осм- «Глобус». Инструкция по применению. - Белгород : ООО «Глобус», 2004. - 51 с.

5. Покровский А. В. Клиническая ангиология / А. В. Покровский. - М. : Медицина, 1979. - 366 с.

6. Педли Т. Гидродинамика крупных кровеносных сосудов / Т. Педли; пер. с англ. - М. : Мир, 1983. - 400 с. 7. Механика кровообращения / К. Каро, Т. Педли, Р. Ротер, У Сид; пер. с англ. - М. : Мир, 1981. - 624 с.

8. Современные неинвазивные методы измерения артериального давления для диагностики артериальной гипертонии и оценки эффективности антигипертензивной терапии : пособие для врачей / А. Н. Рогоза, експериментальній медицині для виявлення захворювань серцево-судинної системи та порушення іiі функціональної здатності.

Е. В. Ощепкова, Е. В. Цагареишвили, Ш. Б. Гориева. - М. : МЕДИКА, 2007. - 72 с.

9. Местные механизмы регуляции кровообращения http://fiziologiya. info/nozdrachev-kmga-vtoraya/8-6-1mestnye-mexanizmy-regulyacii-krovoobrashheniya.html c. 241 .

10. Чащин А. В. Использование биологической обратной связи в современных методах управления и контроля артериального давления / А. В. Чащин // Известия СПбГЭТУ. Биотехнические системы в медицине и экологии. - 2005. - С. 82-84.

11. Патент РФ № 2360596 Способ определения артериального давления, параметров гемодинамики и состояния сосудистой стенки с использованием осциллометрии высокого разрешения / Цупко Игорь заявитель, Цупко Игорь патентообладатель заявл. 24.01.2008 года; опубл. 10.07.2009 года.

12. Пат. на корисну модель № 99426 Україна, МПК А61В 5/02 (2006.01). Спосіб оцінки стану серцево-судинної системи 3 використанням методів морфологічного аналізу осцилограми / Д. В. Вакуленко; Державний вищий навчальний заклад «Тернопільський державний медичний університет імені I. Я. Горбачевського МО3 України». - u201410489; заявл. 25.09.2014; опубл. 10.06.2015, бюл. № 11 . 